\title{
Analysis of Consumption Habits of PostPartum Herbal Concoction in Postpartum Mothers
}

\author{
Sri Banun Titi Istiqomah \\ Faculty of Health \\ Universitas Pesantren Darul Ulum \\ Jombang, Indonesia \\ sribanuntiti@fik.unipdu.ac.id
}

Sri Fatmawati

Department of Chemistry, Faculty of Science Institut Teknologi Sepuluh Nopember Surabaya 60111, Indonesia

\author{
Wiwit Denny Fitriana \\ Faculty of Sciences and Technology \\ Universitas Pesantren Darul Ulum \\ Jombang, Indonesia \\ wiwitdenny@mipa.unipdu.ac.id
}

\author{
Taslim Ersam \\ Department of Chemistry, Faculty of Science \\ Institut Teknologi Sepuluh Nopember \\ Surabaya 60111, Indonesia
}

\begin{abstract}
Postpartum period is the period after the fetus and placenta are born until the recovery of uterine devices such as the condition before pregnancy which lasts for about 42 days. During the puerperium, the body of a mother will experience physiological changes in the physical and psychological changes. So care and monitoring during the puerperium is very important because the possibility of complications can occur. This study aims to determine whether the postpartum herbal medicine consumed by the community is in accordance with the composition of the spices and the time of consumption. This research is descriptive about postpartum herbal medicine which is suitable to be consumed by looking at the composition and time of consumption. The research method is carried out by observation, interview, and documentation. Ten respondents were determined by purposive sampling. The results showed that from 10 respondents all had consumed postpartum herbal concoction. besides, it is known that there are several types of spice mixtures found in the community that are not exactly the type of spice mixture and the time of administration. Therefore, more attention is needed from health workers in providing information to families regarding the composition of postpartum herbal medicine which is right given in the first $\mathbf{4 0}$ days, with a mixture of spices such as meniran, turmeric, jungrahap, licorice, binahong.
\end{abstract}

Keywords- postpartum mothers, postpartum herbal medicine, traditional medicine

\section{INTRODUCTION}

Postpartum is a period after childbirth until the return of mother reproductive body part into normal which usually occurs for 42 days. During this period, the mother's body will have physiological and psychological change. Therefore, it is important to have treatment and observation during this period, since it may occur disease complications.

In general, treatment of health during the postpartum period cannot be separated from social behaviour and culture of the society.

The behaviour involves all people or individual behaviour that contribute to other's health. The behaviour for example a tradition to get postpartum mother consuming traditional herbal medicine such as gepyokan, иуир иуир, galian rapet and galian parem and laxative herb. The consumption aims for increasing mother and baby's health physically and physiology. This also uses to prevent the occurring of infection, quicken the healing of episiotomy sutures [1] and facilitate breast milk production.

The above explanation, inspires the writer to conduct how health treatment for postpartum mother based on Indonesian tradition and culture. This tradition and culture are an effort to have cheap, easy, safe and useful from the ancient till now.

\section{RESEARCH METHOD}

This a descriptive non-experimental study with phenomenology approach. The writer intended to investigate the experiences of respondents in using traditional herbal medicine for postpartum based on its composition and time consumed.

The research method was conducted by observation, interviewed, questionnaire and documentation Purposive sampling was used for getting 10 respondents. The writer set the criteria to be a respondent. A respondent must be postpartum mother, postpartum mother and consume postpartum traditional herbal medicine, stay or live in Ngoro, Jombang district. Meanwhile, the research instrument was interviewing guide, note for field observation, while the questionnaire was filled by respondents. Furthermore, the data was analyzed through, data analysis, data presentation, and conclusión.

\section{RESULT AND DISCUSSION}

This study intended to investigate traditional herbal medicine for postpartum which consumes by postpartum mother has required spices concocted composition and time consumed. Traditional herbal medicine for postpartum is resulting from several medicinal plant which uses to treat mother after childbirth. Postpartum is a period after childbirth until the return of mother reproductive body part into normal which usually occurs for 6 weeks. During this 
period, the mother's body will have physiological and psychological change. These changes often lead to making a complaint and problem for maternal mother. Therefore, it is important to have a treatment and observation during this period, since it may occur disease complications. Disease complications with pre-eclampsia often occurs such as high blood pressures, obesity, swollen legs, headache and visual disturbances[2].

The consumption of traditional herbal for postpartum has not been standardized. Moreover, there are still few studies about the content of traditional herbal medicine for postpartum in detail in every region of Indonesia. Every region has its composition of traditional herbal medicine for postpartum based on their culture and tradition. The results of the study revealed that it is still difficult to determine the accuracy of composition concocted of traditional herbal medicine for postpartum. The people still use a handful, a piece and a divide based on ancestral experience [3]. The composition of traditional herbal medicine for postpartum by effects the effectiveness of the activity and toxicity of this herbal. The followings are the results interview of 10 respondents:

"Taste of Traditional herbal medicine Gepyok is bitter. I drank it every morning and evening, a week after the childbirth. The effect was the blood did not smell fishy; breast milk production is good. I did not know exactly about the composition. I got a box of cake that contains powdered herbal. The dosage was 2 spoons traditional which is put in a glass. After that, I gave it with hot water and a few minutes later I drink it (MZ, 3 Februari 2019).

" I drink kunir asem traditional herbal. Meanwhile, I bought a powdered traditional herbal which is called uyupuуир. I drank it after delivering baby. A spoonful of uyupuyup herbal powder is put in a glass of water. After that, it was brewed with hot water for $1 / 2$ of small glass" (DP, 3 Februari 2019)

"I bought herbs per package, taken directly after giving birth. I drank it in the afternoon for 40 days. I brewed hot water into a small glass containing herbal medicine. how to drink it is different. Then, I bought 1 box, it contained several packs of herbal medicine that drank another, the next day, one was taken from day 1 to day 7 , then day 8 to day 20, last day 21 to day 40, the herbs continued for breastfeeding, the blood came out the first minute, the milk went smoothly, I also used Jamu parem by way of being draped on the body, so it didn't get sore and swollen. Besides that, I also use pilis traditional herbal which is smeared on the face and neck to reduce the wrinkle. When using the powder the skin feels cold so that the skin is smoother"'(FN, 3 February 2019)

"I drink herbal medicine made by my mother. For 2 months the herbal medicine is taken twice a day. After drinking the herbal medicine, the blood comes out smoothly, breast milk much too and a lot. Besides that, I have had gastric pain before. But after drinking herbal medicine for 3 weeks, the stomach feels comfortable and it never appears again "(SR, 3 February 2019)

"I drank gepyok traditional herbal. I bought it in the form of stew, 1x1, for 40 days, sugar brown sugar must use palm sugar. The effect is a lot, the body feels good, it is not easy to get tired of staying up late, the milk is smooth, so I like to eat, it doesn't make it slim "(ZY, 3 February 2019)
"I drank homemade traditional herbal medicine. Sometimes I drink kunir kencur traditional herbal added with kampong chicken egg yolks. Besides that, I drank also dates soaking water, $200 \mathrm{ml}$ hot water plus 3 seeds. The drink then is drunk when it becomes warm. After 6 months, I continue to drink herbal medicine such as Turmeric, kencur, temulawak, temu putih, adas pulo waras, puyang, cinnamon, boiled. After being warmed then, it is given orange honey, 1x1, 200ml "(K, 3 February 2019)

"I drank gepyokan traditional herbal for 2 weeks. The drink schedule is morning and evening, 1 tablespoon of herbal medicine powder is put in a glass and brew $1 / 2$ cup of clean boiled water, plus enough honey "( $\mathrm{T}, 3$ February 2019)

"I drink galian rapet traditional herbal from the herbal store. I drank it for 40 days. The herbs were placed in glass that had been given water and boiled 20 minutes on low heat. The way to drink the herbal medicine is $1 / 2$ cup mixed a little honey "(A, 3 February 2019)

"I drank powdered of gepyokan herbal medicine and extract of galian parem. The composition Inside the herbal is temu lawak, kayu ules, jungrahap leaf, cardamom, turmeric, fennel, chili, fried pulosari. All are mixed and blended. The way to drink is 1 spoon brewed with $1 / 2$ cup of hot water plus honey. Time to drink is in the morning and evening "(W , February 2019)

"I drank herbal medicine to facilitate breast milk. Its contents are katu leaf powder, $1 / 2$ cup hot water and 1 teaspoon of katu leaf powder. I drink it 3 times a day "(S, February 2019)

Based on the decision of the Minister of Health of the Republic of Indonesia No. 381/2007 concerning National Traditional Medicine Policy, it is necessary to conduct a scientific study to ensure that traditional medicines are safe, useful and protect the public from inappropriate one.

All aspects have to get supported by the knowledge and alertness of the community to choose ingredients that are safe for consumption by postpartum mothers. The goal is not only for her physical condition but also for her baby's lactation preparation. Therefore, to support the result of interviewing, the writers spread questionnaire to assess the level of postpartum mother's knowledge on the composition of traditional herbal medicine for postpartum which is consumed and the benefits of every kind of traditional herbal medicine they make. Based on the questionnaire of postpartum mother's knowledge on the composition of traditional herbal medicine shows that they have lower knowledge of traditional herbal medicine and every concoction of traditional herbal medicine for postpartum [4].

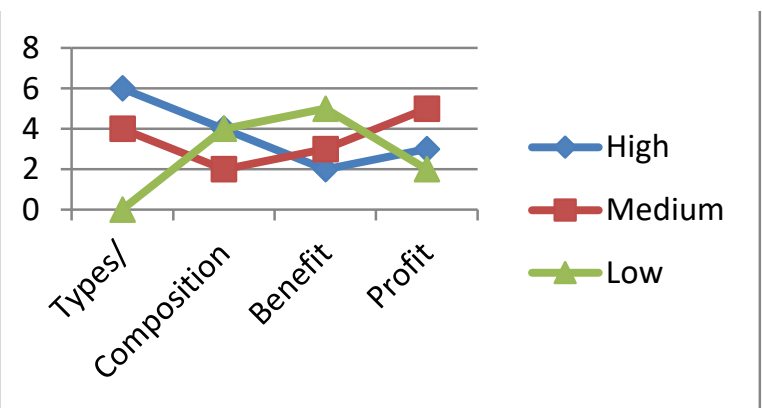

Diagram 3.1 Level of knowledge on postpartum mother about traditional herbal medicine for postpartum 
Besides, supported by observation result, where during field observation, the writers found there were only 3 from 10 respondents prepared this traditional herbal by them self. Meanwhile, 5 respondents got prepared by their family, and 2 respondents bought it.

In the meantime, based on the place they live, 6 respondents live in the village, 4 respondents live in the urban area. Furthermore, based on their experiences, 6 respondents are involved as grand multipara, and 4 are primipara.

Research on the effectiveness of the composition of postpartum traditional herbal medicine in terms of antioxidant bioactivity and toxicity to mice was carried out by [5]. The results explained that 2 variations in the composition of postpartum herbs, phytochemical tested for each variation in postpartum herbal composition secondary metabolites in herbal medicine for postpartum.

The composition of the 1 st traditional herbal medicine for postpartum is meniran, turmeric, jungrahap leaf, licorice and binahong with a total weight of 5 grams. Meanwhile, the composition of the second traditional herbal medicine for postpartum is bangle, lempuyang, tamarind, majakani, and turmeric which each of weight is 1 gram with a total weight of 5 grams for all.

Additionally, still from [6], the result of screening on both the composition of traditional herbal medicine shows that polyphenols compound of traditional herbal medicine for postpartum 1 is higher than 2. Additionally, traditional herbal medicine for postpartum 1 has higher tannin than 2 [7]. However, both have similar saponins. Furthermore, traditional herbal medicine for postpartum 1 has higher alkaloids than 2. Meanwhile traditional herbal medicine for postpartum 1 has higher flavonoid content.

\section{CONCLUSION}

Based on the result of 10 respondents, it can be concluded that the knowledge of postpartum mothers regarding the composition of traditional herbal medicine for postpartum and the benefits of each type of herbal medicine on the concoction are low [8]. This can arise due to some factors, such as the level of education, the experience of being a postpartum mother, and the culture of the neighborhood [9]. Besides traditional herbal medicine for postpartum practice is still higher than another which aims to preserve jamu as the Indonesian traditional herbal medicine cultura [10], while at the same time modern medicine exists. It happens which is caused by the influence of their family such as their mother, parents in lawor grandmother. The traditional herbal medicine such as gepyokan, uyup uyup, galian rapet and galian parem are the most famous used by postpartum mother in Indonesia [11]. They buy powdered herb and concocted herb to boiling at home [12]. These herbs are mostly from medicinal plant family. Based on phytochemical screening, the content variation of first traditional herb medicine for postpartum is higher than the second [13].

\section{ACKNOWLEDGMENT}

Acknowledgement: This work was supported by a funding from research project for national research collaboration and scientific publication between universities year 2018, number of contract 001/K7/KM/SP2H/PENELITIAN/2019, Directorate General of Higher Education, Ministry of Education and Culture, Indonesia.

\section{REFERENCES}

YM Oci. Herbal Sehat \& Aman Untuk Ibu Hamil \& Nifas. Klaten: Cv Sahabat; 2012

Yanti.D \& Sundawat.D, 2011, Asuhan Kebidanan Masa Nifas, Refika Aditama, Bandung.

[3] Usemahu, K.M., Rachman, W.A., Natsir, S., 2014, Traditional Medicine Behavior on Maternal Postpartum in the Village of Kailolo Central of Maluku, Promosi Kesehatan dan Ilmu Perilaku FKM Universitas Hasanuddin.

Putri, D. A. \& Fatmawati, S., 2019. A New Flavanone as a Potent Antioxidant Isolated from Chromolaena odorata L. Leaves. Evidence-Based Complementary and Alternative Medicine, Volume ID 1453612, pp. 112.https://www.hindawi.com/journals/ecam/2019/1453612/ab s/

[5] Fatmawati, S., Ersam, T. \& Shimizu, K., 2014. The inhibitory activity of aldose reductase in vitro by constituents of Garcinia mangostana Linn.Phytomedicine, Volume 22,pp. 4951.https://www.sciencedirect.com/science/article/pii/S094471 $131400381 \mathrm{X}$

[6] Fitriana, W. D., Istiqomah, S. B. T., Ersam, T. \& Fatmawati, S., 2018. The Relationship of Secondary Metabolites: A Study of Indonesian Traditional Herbal Medicine (Jamu) for Post Partum Maternal Care Use. Surabaya, AIP Conference Proceedings.https://aip.scitation.org/doi/abs/10.1063/1.50825 01

[7] Fitriana, W. D., Ersam, T., Shimizu, K. \& Fatmawati, S., 2016. Antioxidant Activity of Moringa oleifera Extracts.Indonesian Journal Chemistry,16(3), pp. 297301.https://journal.ugm.ac.id/ijc/article/view/21145

[8] Y Fitrianti, TJ Angkasawati, 2015, Pengobatan Tradisional Gayo Untuk Ibu Nifas, (Gayo's Traditional Medication For Puerperal Mother).Buletin Penelitian Sistem Kesehatan - Vol. 18 No. 2 April 2015: 111-119. https://www.researchgate.net/profile/Tri_Angkasawati/publica tion/313383525_Gayo\%27s_Traditional_Medication_For_Pu erperal_Mother/links/59687feba6fdcc18ea6c1375/GayosTraditional-Medication-For-Puerperal-Mother.pdf

[9] Handono, K., Hasanah, D., Kalim, H. \& Mawarti, H., 2013. The Association Among Serum Levels of Vitamin D, TGF- $\beta$ /IL-6 Balance and Treg/Th17 Balance in Systemic Lupus Erythematosus Patients in Indonesia. International Journal of Biochemistry and Biotechnology2, pp. 490-496. https://pdfs.semanticscholar.org/a85e/0f7fe6d8320fe7a37b61f 2f83e3342aa1cea.pdf

[10] Istiqomah, S.B.T., Triloka, W., \& Azizah, N., 2014, Pengaruh Buah Papaya terhadap Kelancaran Produksi ASI pada Ibu Menyusui di Desa Wonokerto Wilayah Puskesmas Peterongan Jombang Tahun 2015,Eduhealth, Volume 5 (2). pp. 102108.https://www.journal.unipdu.ac.id/index.php/eduhealth/arti cle/view/477

[11] Istiqomah, S.B.T., Mufida, N., 2014, Hubungan Tingkat Pengetahuan Ibu Nifas Paritas I Tentang Perawatan Bayi Baru Lahir Dengan Kejadian Hipotermi. Eduhealth. Volume 4 (1) pp.47-52 
https://journal.unipdu.ac.id/index.php/eduhealth/article/view/ 453

[12] SBT Istiqomah, WD Fitriana, 2018, The Effect of Hot Chocolate Drinks to Decrease Anxiety toward Mother in First Stage ofLabor,The 2nd Joint International Conferences2 (2)pp. 503508.http://proceeding.tenjic.org/jic2/index.php/jic2/article/vie w/79

[13] Istiqomah, S.B.T., Yani, Puspita, D., \&Suyati , 2018, Pengaruh Efektifitas Pemberian Seduhan Daun Peppermint pada Ibu
Hamil Terhadap Penurunan Frekuensi Emesis Gravidarum,Jurnal EDUMidwifery. Volume 1 (2). pp. 103107.https://journal.unipdu.ac.id/index.php/edumidwifery/articl e/view/1062 